\title{
Measures of Current Monetary Developments
}

$V_{A}$ ARIOUS MONETARY ACTIONS have been taken since last fall, with the objective of restraining exuberance in the economy. The discount rate was increased in three steps from 4 to 5.5 per cent. Reserve requirements on demand deposits of over $\$ 5$ million were increased by one-half percentage point. Reserves have been provided less rapidly through System open market operations.

Recent movements in these monetary instruments indicate that policy actions have become restrictive. An examination of some of the major indicators of monetary action, however, suggests that there has been less monetary restraint than a cursory review of the policy moves and the current trends in frew quently cited proximate measures of monetary action would indicate. Some of the movements of the proximate guides have probably reflected the influence of factors other than policy actions.

\section{Current Economic Conditions}

The recent policy actions have been taken to combat excessive aggregate demand. Economic expansion in 1967 was spurred by stimulative monetary developments and rapid growth in Government demand for resources. Since late in 1967 monetary expansion has slowed somewhat, and the extent of fiscal stimulus has moderated slightly; but both remain expansionary relative to most of the post-war period. In lagged response to the expansionary policies of last year, private demand, especially from the consumer sector, has accelerated sharply since the fouth quarter. The marked rise in the demand for goods and services, reinforced by increases in costs of production, has intensified the upward pressure on prices. The rapid expansion of demand has been excessive, relative to the rate of increase in production, and has contributed to a 4 per cent rate of increase in prices since last summer.

\section{merest Tares}

Interest rates, frequently used as a proximate guide to monetary actions, generally have risen since last November. The sharpest rise has been experienced in the market for short-term securities, with the yield on three-month Treasury bills increasing

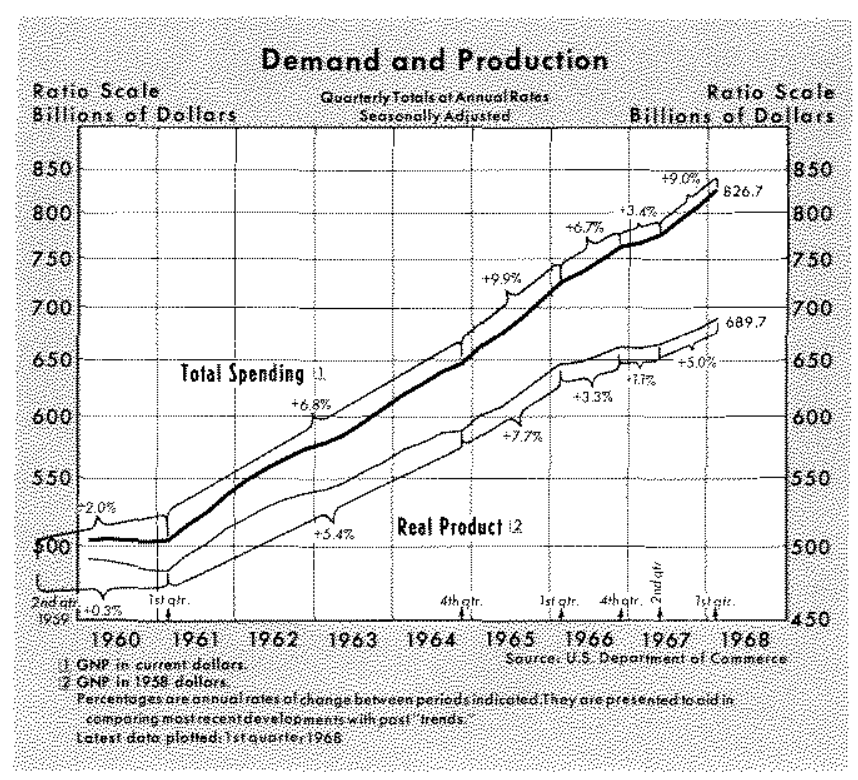


from an average of 4.72 per cent in November to 5.66 per cent in early June. The extent to which the rise in rates has reflected monetary restraint is difficult to determine. Government deficit financing, which has been concentrated in short-term maturities, has placed a large supply of new securities on the market at a time when the Government is normally a net repayer of debt and has placed upward pressure on yields.

In addition, market expectations of continued inflation tend to put upward pressure on interest rates. Lenders of funds probably demand higher yields to compensate for greater expected future increases in prices. Borrowers, on the other hand, are probably less reluctant to pay higher rates as they anticipate repaying in dollars depreciated by inflation. The accelerated rates of price increases since 1965 have probably contributed to such an inflationary psychology. Adjusted by one method for the expectation of inflation, interest rates have shown little net change since last fall.

While rising interest rates may be consistent with present monetary policy goals, in the current context the amount of increase may not measure ac-

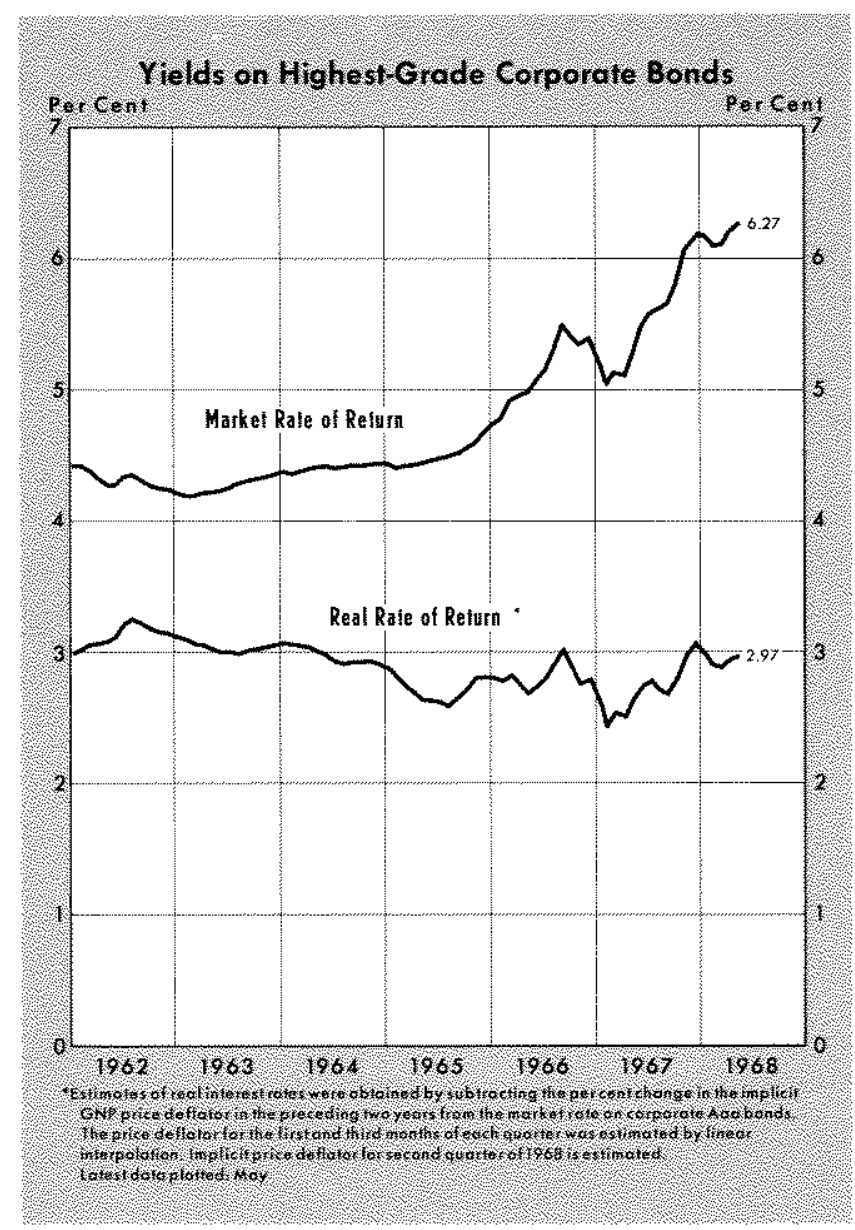

curately the degree of monetary restraint. Rather, they also may reflect changes in economic environment, such as Government financing, upward revisions in business and consumer spending plans, and greater expectations of inflation.

\section{Free Meserves}

The level of "free" reserves (i.e., excess reserves less borrowings from Federal Reserve Banks) declined from $\$ 270$ million in November to a negative $\$ 332$ million in May. According to an interpretation that a fall in free reserves makes banks less willing to extend credit, such a large shift indicates a dramatic move toward restraint.

On the other hand, the shift in "free" reserves merely may have reflected a change in the borrowing patterns of money market banks. Banks may borrow reserves from other commercial banks in the "Federal funds" market or from the Federal Reserve. In November the discount rate averaged 6 basis points above the Federal funds rate, making borrowing from other banks to meet reserve deficiencies attractive relative to borrowing at the discount window. With few exceptions, however, the rate on Federal funds has been above the discount rate since November, reversing the order of attractiveness and giving banks more incentive to borrow from the Federal Reserve. Also, with high and rising shortterm interest rates, especially on one-day Federal funds, banks have a growing incentive to hold excess reserves to a minimum.

\section{Bank Credit}

An aggregate measure of monetary actions is the growth of credit extended by the banking system. The rate of growth of total commercial bank credit has slowed from a 12 per cent annual rate from December 1966 to November 1967, to an estimated 6.4 per cent rate since November. The slowdown is reflected in the reduced rate at which banks have acquired new securities. Growth in loans at commercial banks has changed little, rising at a 7.3 per cent rate since November, compared with a 7.7 per cent annual rate of increase over the first eleven months of last year.

The recent slowdown in the expansion of bank credit has been moderate, however, relative to 1966 , the most recent previous period of monetary restraint. From mid-1961 to April of 1966, bank credit rose at a 9 per cent annual rate. From April to December of that year, as monetary restriction was applied, the rate of growth of bank credit fell to 3.8 per cent. Growth in loans was reduced to a 6.8 per 
cent rate from a 12 per cent rate of increase which had prevailed over the previous period. Investments declined at a 2.1 per cent rate, following a 3 per cent annual rate of increase.

An interpretation of the recent slowdown in bank credit growth is that funds have flowed from savers to ultimate borrowers without passing through the banking system. Since November, banks have become less competitive in attracting time deposits. Since market interest rates rose above Regulation $Q$ ceilings, more funds have flowed into commercial paper and other markets, and fewer funds have been attracted into time deposits in commercial banks. There is little evidence that growth of total credit from all sources to final users has slowed.

\section{Money Stock}

Another proximate measure of the impact of monetary actions on the economy is the change in the growth rate of cash balances held by consumers and businesses. The money stock, private demand deposits and currency held by the public, has increased at a 5 per cent annual rate since November, compared with a 7 per cent rate of rise over most of last year. As an indicator of monetary policy, such a slowdown suggests a gradual move toward monetary restraint. However, the high and rising nature of interest rates may have decreased the demand for money balances. In this context the reduced rate of expansion of the money stock may overestimate the degree of monetary restraint. Supplying money at a slower rate does not dampen spending plans if

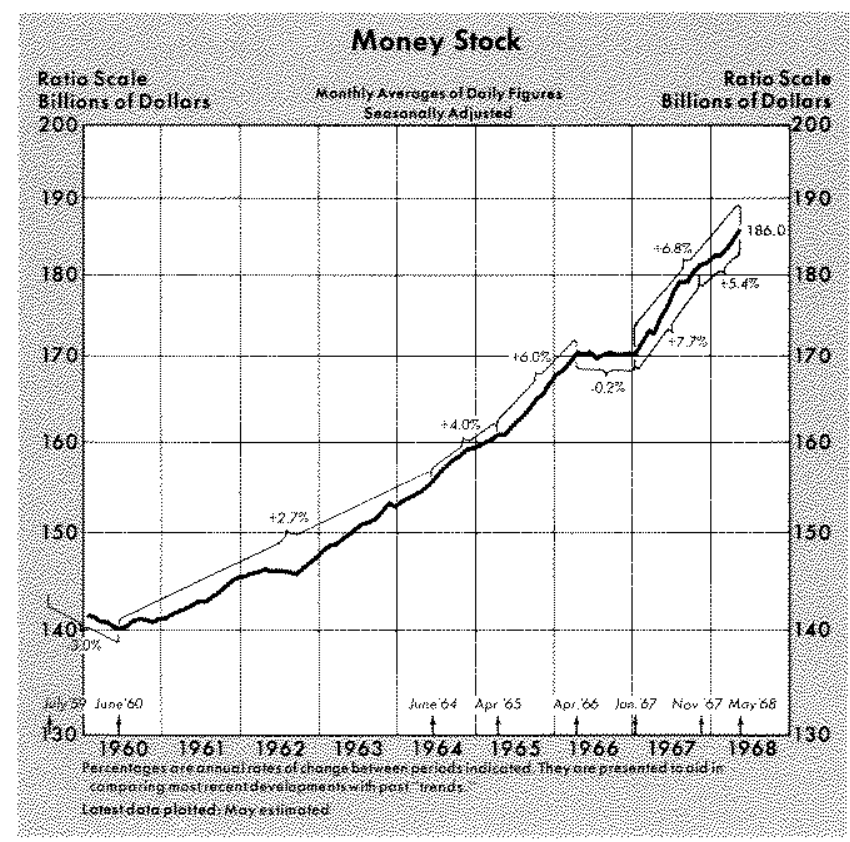

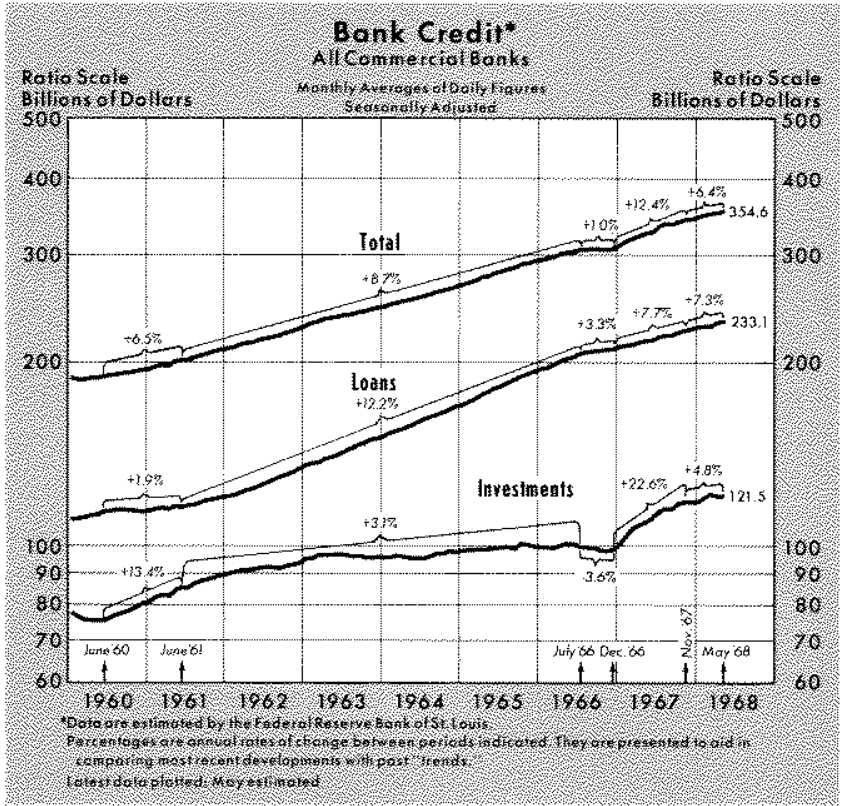

businesses and consumers reduce the rate at which they want to accumulate cash balances. The fact that the income velocity of money rose rapidly from the fourth to the first quarter, after changing little last year, is an indication that the supply of money has tended to exceed the demand for money to hold under existing conditions.

On the supply side, the recent reduction in the rate of growth of money has been very moderate relative to other periods of monetary restraint. For example, the money stock increased at a 6 per cent annual rate from April 1965 to April 1966. During the period of monetary restraint from April 1966 to the end of the year, the money stock showed little net change.

\section{Conchusion}

The growth rate of total demand has been excessive, and the upward pressure on prices has increased. The monetary authority has recognized the need for restraint and has made a number of moves to implement a less expansionary policy. Investigation of the current data suggests that, through the month of May, there may have been some move toward monetary restraint, but that the degree of restraint was less severe than a cursory examination of some of the proximate guides might indicate. Given the fiscal situation and other underlying conditions in the economy, the recent degree of monetary restraint may not have the desired effect of reducing total demand sufficiently to eliminate demand-pull inflationary pressures. 